\title{
On the relationship between atmospheric rivers, weather types and floods in Galicia (NW Spain)
}

\author{
Jorge Eiras-Barca $^{1}$, Nieves Lorenzo ${ }^{2}$, Juan Taboada $^{3}$, Alba Robles ${ }^{2}$, and Gonzalo Miguez-Macho ${ }^{1}$ \\ ${ }^{1}$ Non-Linear Physics Group, Universidade de Santiago de Compostela, Santiago de Compostela, Galicia, Spain \\ ${ }^{2}$ Ephyslab, Universidade de Vigo, Vigo, Galicia, Spain \\ ${ }^{3}$ MeteoGalicia, Consellería de Medio Ambiente, Xunta de Galicia, Santiago de Compostela, Spain
}

Correspondence: Jorge Eiras-Barca (jorge.eiras@usc.es)

Received: 15 April 2017 - Discussion started: 6 June 2017

Revised: 14 May 2018 - Accepted: 25 May 2018 - Published: 13 June 2018

\begin{abstract}
Atmospheric rivers (ARs) - long and narrow structures of anomalously high water vapor flux located in the warm sector of extratropical cyclones - have been shown to be closely related to extreme precipitation and flooding. In this paper we analyze the connection between ARs and flooding in the northwestern Spanish region of Galicia under a variety of synoptic conditions represented by the so-called "weather types", a classification of daily sea-level pressure patterns obtained by means of a simple scheme that adopts the subjective procedure of Lamb. Flood events are identified from official reports conducted by the Spanish emergency management agency (Protección Civil) from 1979 to 2010. Our results suggest that, although most flood events in Galicia do not coincide with the presence of an overhead AR, ARs are present in the majority of severe cases, particularly in coastal areas. Flood events associated with ARs are connected to cyclonic weather types with westerly and southwesterly flows, which occur mostly in winter months. The link between ARs and severe flooding is not very apparent in inland areas or during summer months, in which case heavy precipitation is usually not frontal in nature but rather convective. Nevertheless, our results show that, in general, the amount of precipitation in flood events in Galicia more than doubles when an AR is present.
\end{abstract}

\section{Introduction}

Atmospheric rivers (ARs) are narrow, elongated structures that carry high quantities of water vapor in the lower troposphere. The climatological characteristics of ARs have been recently reviewed by Guan and Waliser (2015), who proved that they exhibit a mean length of about $3700 \mathrm{~km}$ and have average integrated vapor transport (IVT) fields of $375 \mathrm{~kg} \mathrm{~m}^{-1} \mathrm{~s}^{-1}$. ARs are usually found in the warm sector of extratropical cyclones and are associated with the meridional transport of latent and sensible heat from the (sub)tropics to the midlatitudes (Newell et al., 1992; Zhu and Newell, 1998; Gimeno et al., 2010; Gimeno et al., 2014; Gimeno et al., 2016; Ralph and Dettinger, 2011; Lavers and Villarini, 2013; Matrosov, 2013; Neiman et al., 2013; Rutz et al., 2014; Garaboa-Paz et al., 2015; Waliser and Guan, 2017).

There has been a rise in the development of detection algorithms for ARs over the past few years, with significant contributions made by numerous authors (e.g., Lavers et al., 2012; Guan and Waliser, 2015; Eiras-Barca et al., 2016; Brands et al., 2016). Despite the fact that discrepancies in the finer details of their detection remain, all algorithms in the literature rely on an analysis of the integrated water vapor column (IWV) and IVT fields. ARs are always characterized by highly increased values of both variables when compared with surrounding areas. An example of a well-defined AR making landfall on the Iberian Peninsula coast, along with the associated extreme precipitation, can be found in Fig. 1.

Flood events (FEs) are major natural disasters that humans face today, as flooding episodes worldwide are commonly associated with extensive socioeconomic impacts and fatalities. The correlation and causality between ARs and extreme precipitation events have been soundly demonstrated in many parts of the world, including the Iberian Peninsula (Ramos et al., 2015; Eiras-Barca et al., 2016). Nevertheless, few studies have used flood databases to analyze how the impact of 


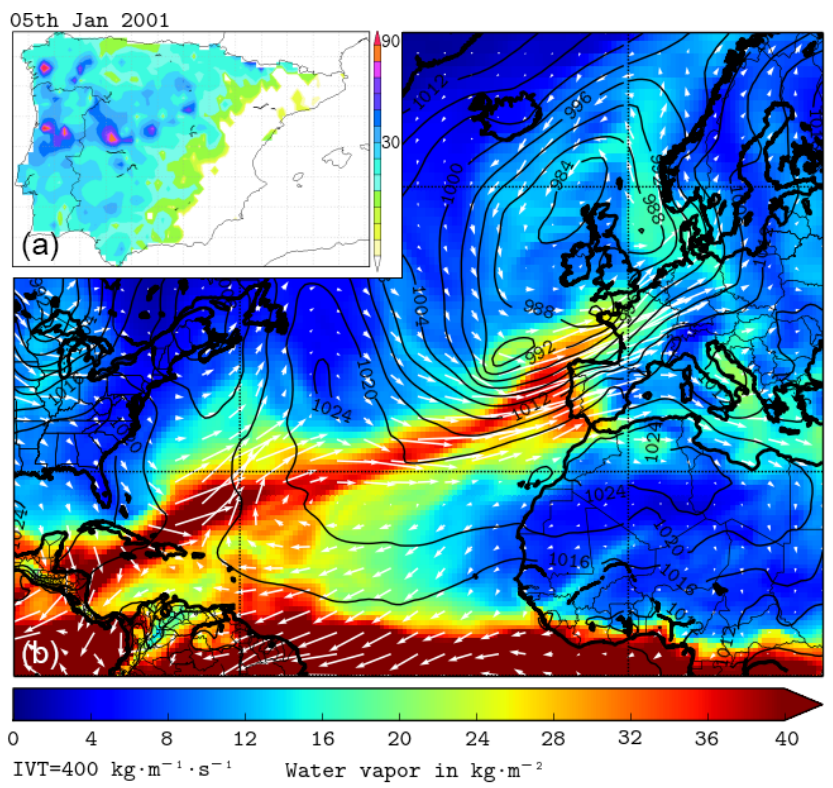

Figure 1. An $A R$ as it makes landfall in Galicia (NW Spain) on 5 January 2001. The field represents the IWV $\left(\mathrm{kg} \mathrm{m}^{-2}\right)$, while the arrows symbolize the integrated water vapor flux or IVT $\left(\mathrm{kg} \mathrm{m}^{-1} \mathrm{~s}^{-1}\right)$. Panel (a) displays extreme precipitation (more than $90 \mathrm{~mm}$ in $24 \mathrm{~h}$ ) accumulated throughout the Iberian Peninsula.

ARs is reflected in people's daily lives. In this regard, the connection between ARs and floods has been extensively established for the west coast of the USA (e.g., Ralph et al., 2006; Dettinger, 2011), as well as for some European regions (e.g., Lavers et al., 2011).

The region of Galicia is located in the northwestern part of Spain. The Galician climate is highly influenced by its location within the North Atlantic storm track, where a continuous passage of baroclinic structures increases the possibility of heavy rainfall episodes (Nieto et al., 2011). This is especially true in winter and autumn, whereas in spring and summer, as the storm track moves poleward, intense precipitation associated with convective episodes plays a more prominent role (Eiras-Barca et al., 2016).

The interannual variability of rainfall in Galicia is mostly linked to certain modes of the atmosphere (e.g., Lorenzo and Taboada, 2005; Lorenzo et al., 2006, 2008, 2011), particularly the North Atlantic Oscillation (NAO), which modulates the position of the storm track and its impact in this region. Therefore, higher correlations that explain the variability in precipitation, especially in southern Galicia, correspond to this index (Trigo et al., 2008). Notwithstanding, other teleconnection patterns such as the eastern Atlantic (EA) or the Scandinavian pattern (SCAND) should also be taken into account when explaining the interannual variability of precipitation and AR activity in Galicia (e.g., Lorenzo et al., 2006; Bueh and Nakamura, 2007; Ramos et al., 2015).

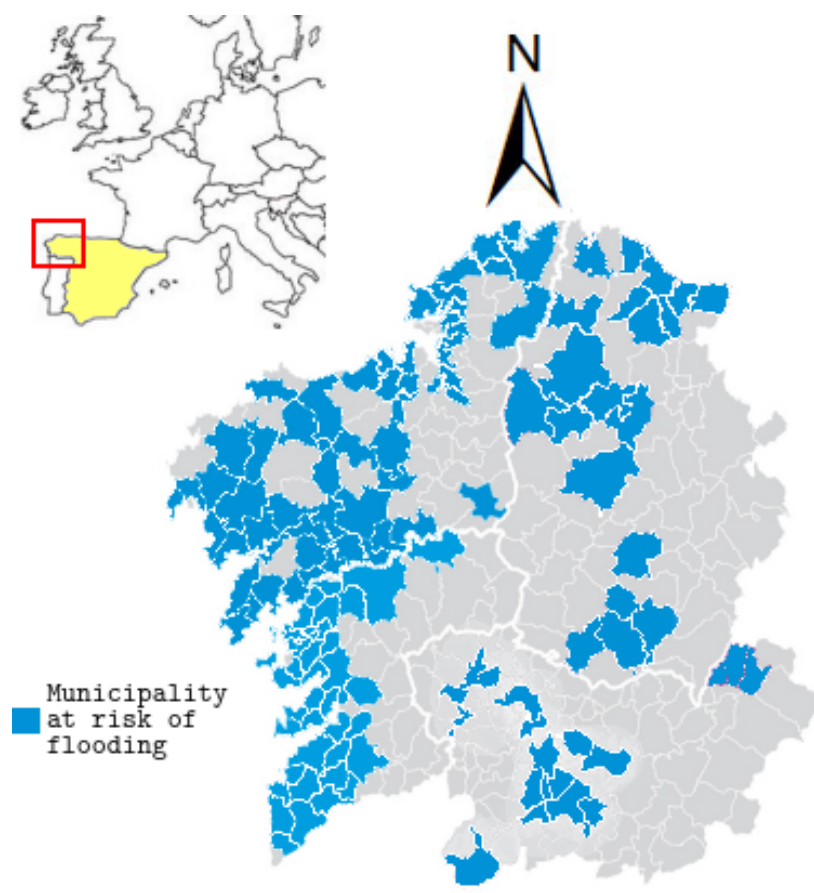

Figure 2. Municipalities of Galicia that are at regular risk of flooding. Sources: the regional government (Xunta de Galicia) and Miño-Sil river authority Confederación Hidrográfica Miño-Sil.

Extreme precipitation and anomalous winds are the most frequent climate risks in Galicia. In coastal towns, floods are more common (Fig. 2) and the corresponding socioeconomic impacts are the most severe (Martínez and Ezpeleta, 2000). Fatalities and serious damage to transportation and communication systems are common when FEs occur. Due to this, a better understanding of the meteorological conditions that produce FEs is crucial for the people and economy of this Atlantic region (Cabalar-Fuentes, 2005).

One way to integrate different meteorological parameters, such as rainfall, direction and wind intensity, or temperature, into a single index is via the classification of synoptic situations (i.e., weather types, WTs). Using data such as sealevel pressure (SLP) or geopotential height for classification, each observed time period is assigned a WT, allowing the associated meteorological variability and its consequences to be studied in different fields in a simple and decipherable way (e.g., Trigo and DaCamara, 2000; Lorenzo et al., 2008; Cortesi et al., 2014; Gilabert and Llasat, 2018). In this article, we look at the occurrence of FEs and their related WTs in Galicia.

With the following research, we analyze the connection between ARs and FEs under different WT synoptic situations. The scope of this paper is twofold. We first identify the relationship between ARs and FEs under different synoptic conditions in the studied region. We then demonstrate how this study may be of use in properly understanding and predicting FEs. The structure of the paper is as follows: in 
Sect. 2 we present our analysis methods, while in Sect. 3 we outline our obtained results and give a brief analysis. Finally, our conclusions are presented in Sect. 4.

\section{Data and methods}

This research aims to analyze the connection between ARs and flood events. Therefore, rather than extrapolate ordinary precipitation databases, we have employed a flooding events database published by the Spanish Emergency System (Protección Civil de España), in which only occurrences with serious implications in terms of damage are considered.

FEs were gathered from official reports published by the Spanish Emergency Service. This database registers FEs over an extended period, i.e., from 1979 to 2010 (Interior, 2014). Two different areas were individually analyzed: the Galician coast (COSTA) and the Miño-Sil (SIL) hydrological units (river basins). Whereas the former unit encompasses all smaller Atlantic basins and is representative of coastal towns, the latter corresponds to the Miño-Sil river basin and depicts conditions inland of Galicia. The rainfall database has been used to quantify the exact amount of precipitation only on flooding days.

The total number of days on which an AR has been detected on the Galician coast during years 1979-2010 is 754 . We note that the same AR event can extend for more than one day. In the same period, 15 and 24 flood events were registered for the SIL and COSTA regions respectively. Since each FE can also last for several days (see Table 1), the total number of days encompassed by all considered FEs is 357 for the SIL and 548 for the COSTA regions.

The database published by Guan and Waliser (2015) was used in the detection of ARs. This is an advanced AR database, with the ability to identify ARs using complex considerations regarding the characteristics of IWV and IVT fields in terms of coherence and continuity (Waliser and Guan, 2017). Equations (1) and (2) represent the methodologies for the integration of the IWV and IVT fields, respectively, where $q$ is the specific humidity, $g$ is the gravitational force, $\boldsymbol{u}$ is the horizontal wind field and the integration covers the whole troposphere from the first pressure level $\left(P_{0}\right)$ to the top $\left(P_{f}\right)$.

$$
\begin{aligned}
& \mathrm{IWV}=\frac{1}{g} \int_{P_{0}}^{P_{f}} q \cdot d p \\
& \mathrm{IVT}=\left|\frac{1}{g} \int_{P_{0}}^{P_{f}} q \cdot \boldsymbol{u} \cdot d p\right|
\end{aligned}
$$

Only days on which ARs made landfall onto the Galician coast have been taken into consideration throughout this analysis (AR days). The classification of synoptic situations
Table 1. Total number of days included in any of the flood events in Galicia throughout the period 1979-2010.

\begin{tabular}{lrc}
\hline Season & SIL region & COSTA region \\
\hline DJF & 206 & 190 \\
MAM & 45 & 102 \\
JJA & 9 & 102 \\
SON & 97 & 154 \\
\hline
\end{tabular}

was done by adopting the procedure developed by Trigo and DaCamara (2000), which was adapted from Jenkinson and Collison (1977) and Jones et al. (1993). The southerly flow (SF), westerly flow (WF), total flow (TF), southerly shear vorticity (ZS), westerly shear vorticity (ZW) and total shear vorticity $(Z)$ were computed using SLP values collected for the 16 grid points shown in Fig. A1 (Lorenzo et al., 2008). For the index calculations, we applied the equations outlined by Lorenzo et al. (2008) to an NCAR reanalysis of size $2.5^{\circ} \times 2.5^{\circ}$. We used the conditions established by Trigo and DaCamara (2000) to define the different WTs. For the sake of simplicity, only WTs that appeared with a frequency of over $3 \%$ are considered in this study. Under this condition, the total number of WTs is 9 throughout the extended winter months (ONDJFM) and 12 throughout the extended summer months (AMJJAS). SLP composites for each of the considered WTs are shown in Fig. 3. A brief description of each WT can be found in Table 2.The hybrid WTs are a combination of both WTs. Finally, ECMWF ERA-Interim reanalysis data (Dee et al., 2011) were used to make composites of the SLP, IVT and IWV variables on days with or without the occurrence of ARs and FEs.

\section{Results and discussion}

The connection between WTs and FEs has been studied using two distinct procedures. First, in Sect. 3.1 we refer to the aforementioned connection in terms of the corresponding WTs that they are associated with. Then, in Sect. 3.2, we demonstrate that the anomaly composites for different variables show whether or not an AR is detected simultaneously with an FE. Finally, the set of meteorological stations stated in Table A1 is used to quantify the amount of precipitation that occurred throughout the FEs.

\subsection{Weather types}

Figure 4 shows the frequency of occurrence for each of the winter and summer WTs during the FEs, for both (COSTA and SIL) regions. For these two regions, ARs are primarily correlated with FEs in winter months. FEs during summer months are mostly associated with anticyclonic situations (NE, A, AE) that block the arrival of fronts and ARs. This is in line with the convective character of extreme pre- 
Table 2. A brief description of the pure predominant WTs used in the analysis. The bulk of this information was obtained by Ramos (2012).

\begin{tabular}{|c|c|c|}
\hline WT & Season & Brief description \\
\hline $\mathrm{NE}$ & Summer & Extended high pressure settled over the west of Ireland and low pressure in the Mediterranean Sea. \\
\hline $\mathrm{E}$ & Summer & Synoptic situations characterized by high pressure over the British Isles and low pressure dominating over northern Africa. \\
\hline SE & Winter & Low pressure extending towards Madeira and high pressure over northern Europe. \\
\hline $\mathrm{S}$ & Summer, Winter & High pressure over the British Isles and low pressure established in the North Atlantic (Azores region). \\
\hline SW & Winter & Low-pressure system to the west of Ireland with a large anticyclone over the Mediterranean region. \\
\hline $\mathrm{W}$ & Summer, Winter & Low-pressure system over the North Atlantic with a high-pressure system over the Azores. \\
\hline NW & Summer, Winter & Low-pressure system over the British Isles and a anticyclone system located over the Azores. \\
\hline $\mathrm{N}$ & Summer & Azores high pressure near the islands and a low pressure over southern Europe and the Mediterranean basin. \\
\hline $\mathrm{C}$ & Summer, Winter & Low-pressure center over the NW Iberian Peninsula \\
\hline A & Summer, Winter & Extended high-pressure center between the Iberian Peninsula and the Azores Islands. \\
\hline
\end{tabular}
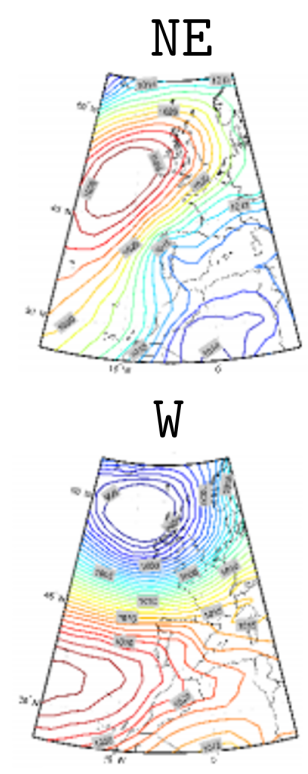
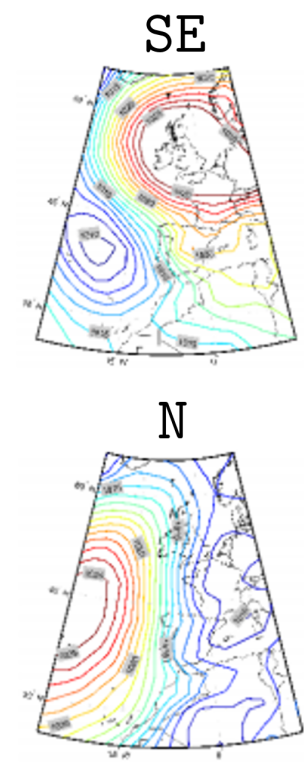

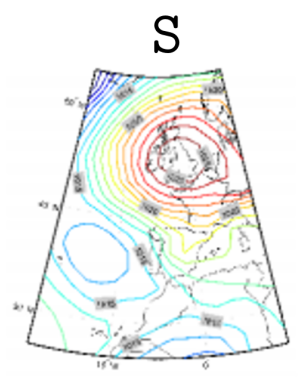

C

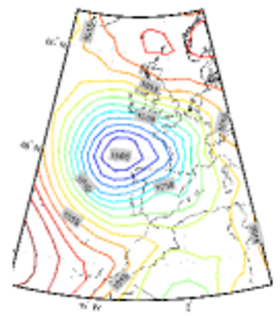

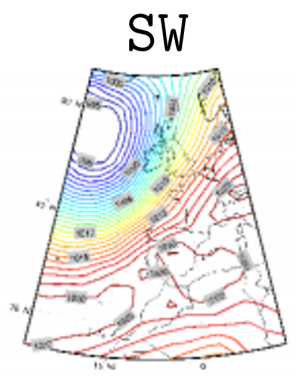

A

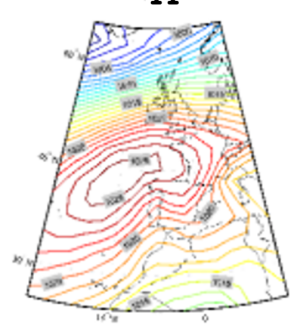

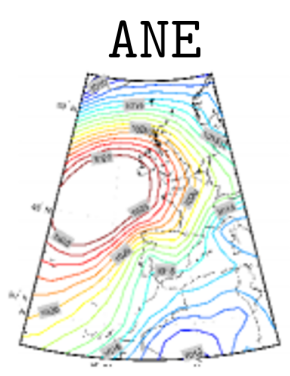
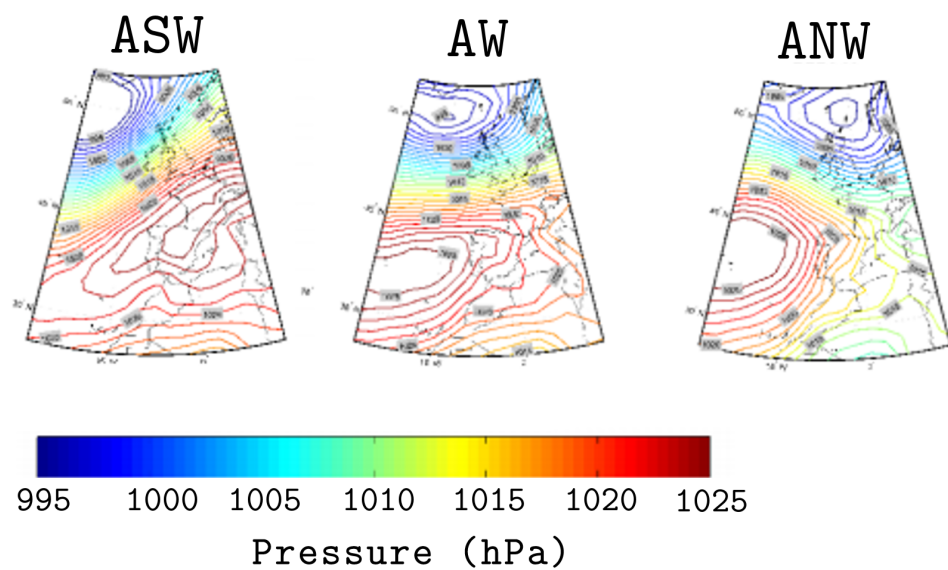

Figure 3. SLP composites for all the WTs considered in this analysis.

cipitation in the extended summer months for these regions. In winter months, however, FEs are mostly associated with W, SW, C and NW WTs, all of which are connected with cy- clonic synoptic situations or situations with humid west flux. Under these conditions, the arrival of fronts to the Galician coast is very likely. The case of the SW weather type is par- 


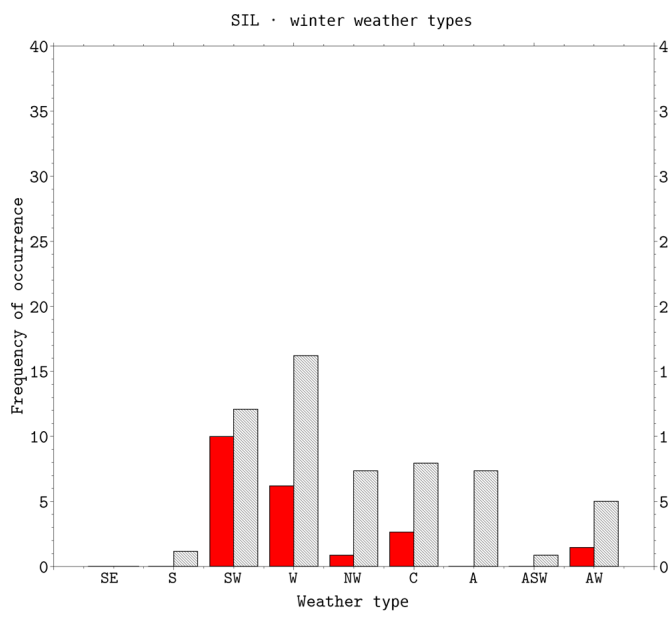

(a)

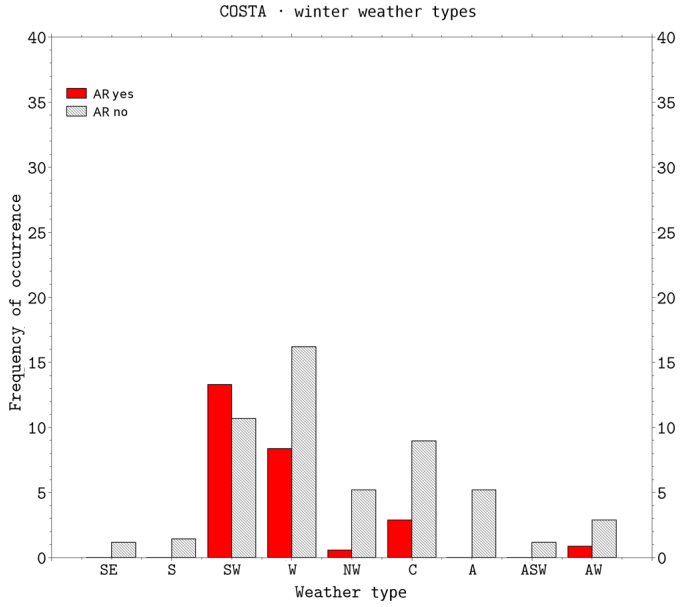

(c)
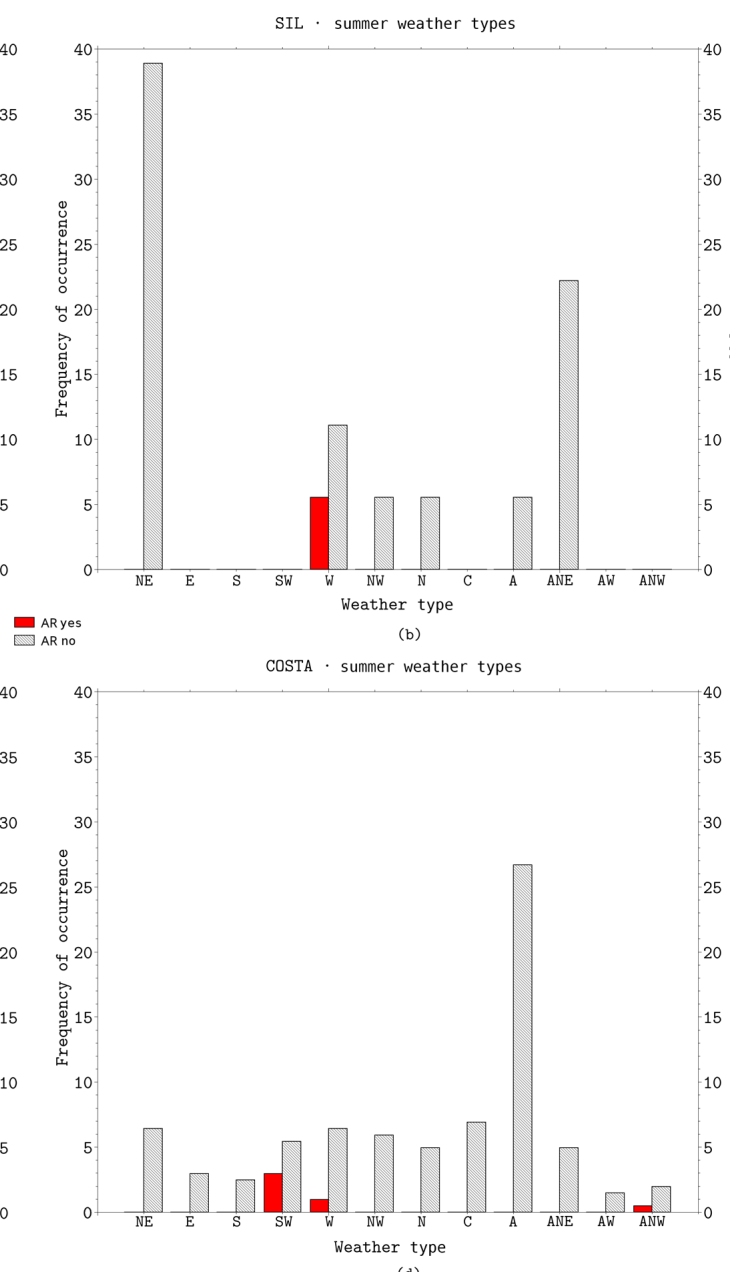

(d)

Figure 4. Frequency of occurrence for each WT with FE for the SIL region in the extended winter (ONDJFM) (a) and extended summer (AMJJAS) (b) months, as well as for the COSTA region in the extended winter (c) and extended summer (d) months. Red bars represent WTs associated with FEs when an AR has been simultaneously detected, while black lined bars refer to FEs that do not have an associated AR event.

ticularly remarkable, as it registers as many floods associated with AR events as floods not associated with AR events. As Fig. 3 indicates, this WT is characterized by the presence of a cyclone near the British Isles, which enhances the arrival of fronts to the Iberian coast. The same applies, though to a lesser extent, to the W, C and NW types.

However, it is necessary to consider that periods of flooding do not always coincide with periods of extreme rainfall due to the fact that 1 or 2 days of heavy rainfall can produce floods that can be maintained over time simply with rainfall quantities that are close to normal amounts. Therefore, to study the relationship between FEs and the presence of ARs in more detail, we have chosen the day with the highest rainfall in each flood period and looked for the presence of ARs on that specific date. Most FEs did not simultaneously occur with an AR when all days of an FE were considered. However, Table A2, exhibiting days where maximum precipitation overlaps with AR detection, indicates that for the COSTA basin, 16 out of the 23 days with the highest rainfall in the FEs $(70 \%)$ took place with the presence of an AR over Galicia. In the SIL region (Table A3), 7 out of 17 (41\%) coexisted simultaneously with an AR. However, if only the extended winter is analyzed in the same database, ratios of 15 out of $19(79 \%)$ and 7 out of $13(54 \%)$ appear for the COSTA and SIL basins, respectively. Once again, our results point to the key role that ARs play in FEs in the COSTA region. This role is diminished farther inland due to the more likely convective character of extreme precipitation over these areas.

Figure 5 shows, for each WT and each region, the precipitation ratio occurring when an AR is (or is not) detected in the context of all the precipitation that occurred in the corresponding WT when there was flooding.

First, the mean precipitation was calculated for each WT, then we computed the accumulated precipitation during the flooding days simultaneously with the WT under considera- 

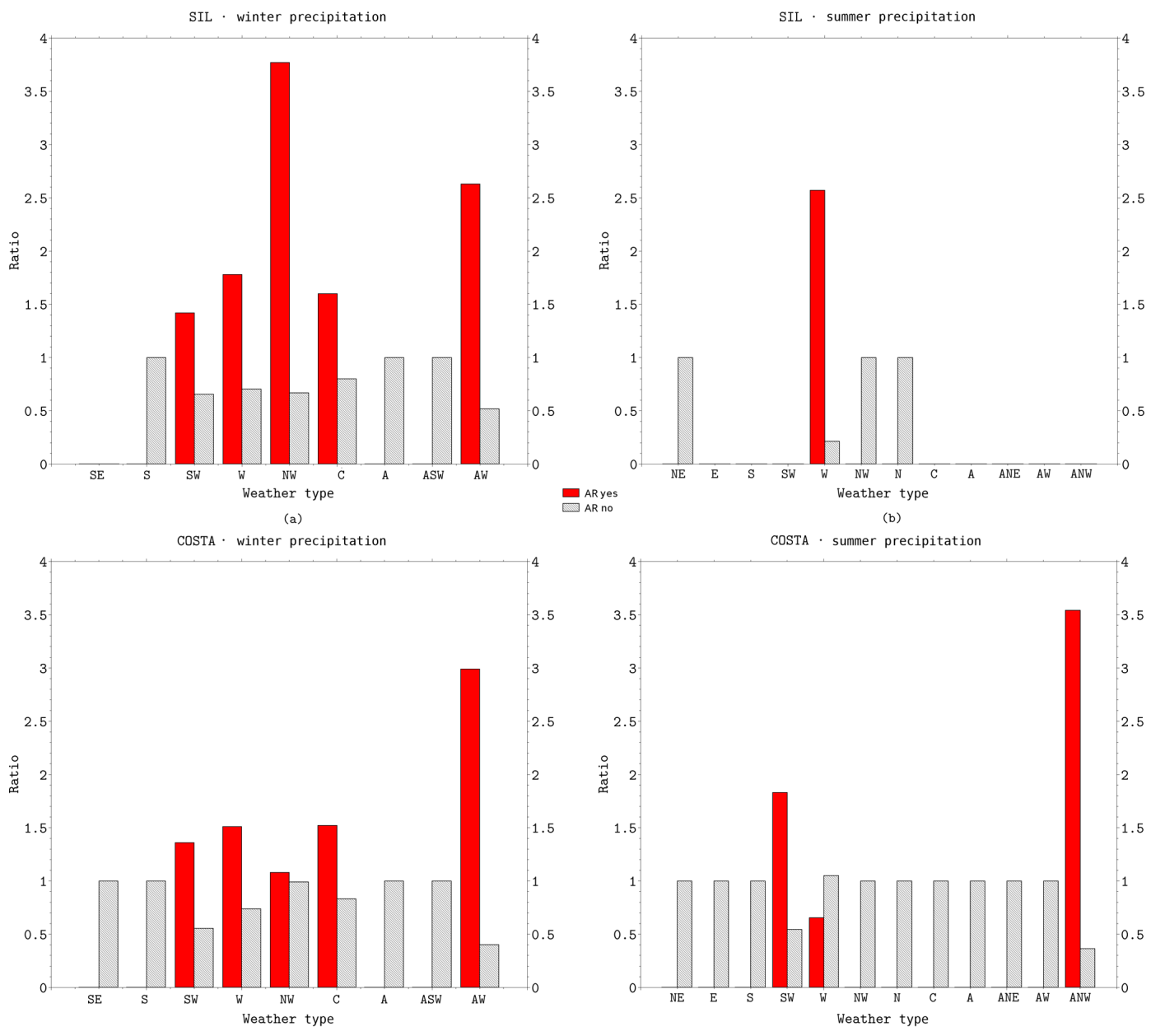

(c)

Figure 5. Same as Fig. 4 but with precipitation ratio.

tion. Subsequently, the mean precipitation in FEs was calculated and separately considered according to the AR detection. The cited ratio is the result of the division of the latter by the former. Thus, this ratio quantifies how much precipitation should be expected when an FE coincides with an AR, with respect to an FE that is not accompanied by an AR for one of the WTs considered. In general, the expected rainfall on a day with an AR within a flood period is more than double than that which is expected on the same day without an AR. Especially noteworthy are the ANW type for the SIL and COSTA regions and the NW for the SIL region, where the expected amount of winter rainfall was 5 times larger than if the FE coincided with an AR (relative to when no AR was detected).

The same occurs, although to a lesser extent, for types SW, W and C for winter precipitation in SIL and with types SW, $\mathrm{W}, \mathrm{NW}$ and $\mathrm{C}$ for winter precipitation in COSTA. In the summer months, the same occurs for the $\mathrm{W}$ types for the interior region (SIL) and the AN type for coastal regions. Even when SW is not the predominant weather type in the summer months, the occurrence of the WT in this season represents the few fronts with ARs arriving on the Galician coast. It is uncommon to observe AR precipitation from WTs other than $\mathrm{W}$ or SW in summer months.

Previous works that analyzed precipitation using the methodology of WTs concluded that most of the yearly and winter precipitation is associated with WTs C, SW and W (e.g., Trigo and DaCamara, 2000; Lorenzo et al., 2008; Cortesi et al., 2014). Our results corroborated with those obtained by the cited studies, contributing to the idea that ARs are responsible for most of this precipitation.

\subsection{Anomaly maps}

Figure 6 shows anomaly composites with regard to the mean sea level pressure for each point in the Atlantic Ocean, which delineates when an AR is and is not detected in Galicia, as well as when an FE is and is not detected over the same region for both the extended winter and summer months. With regards to the winter maps and always speaking in terms of the most probable situation, for an AR to be detected on the 


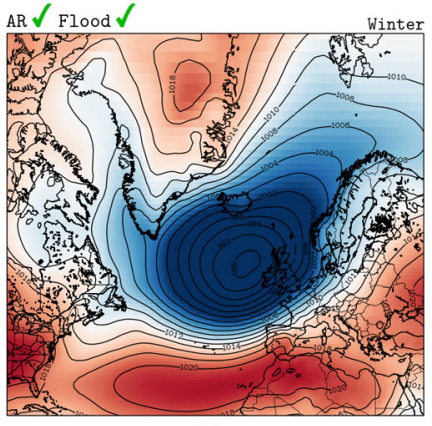

(a)

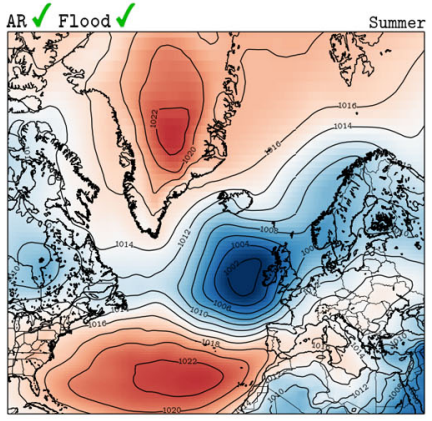

(e)

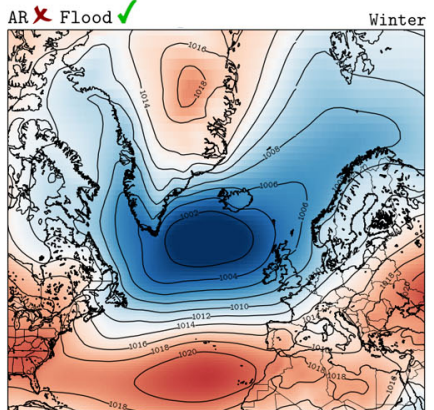

(b)

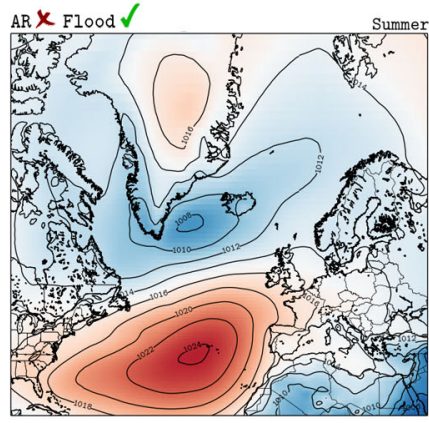

(f)

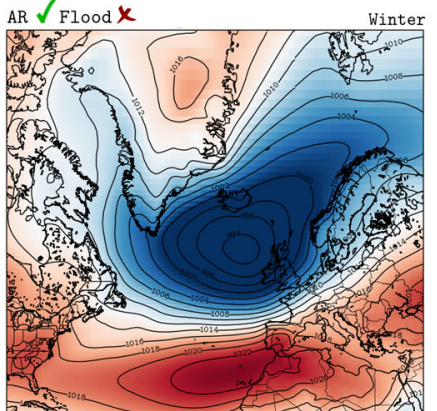

(c)

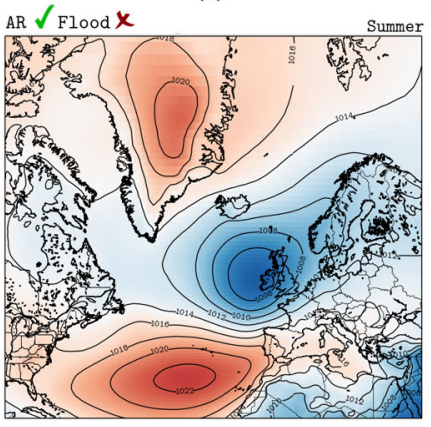

(g)

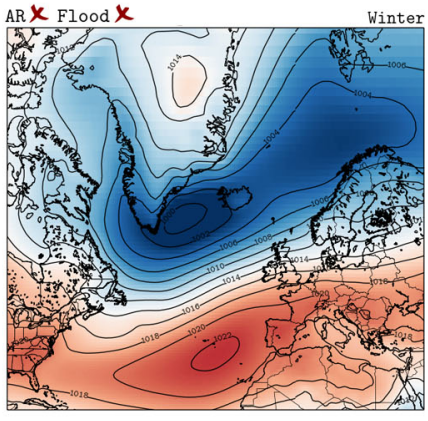

(d)

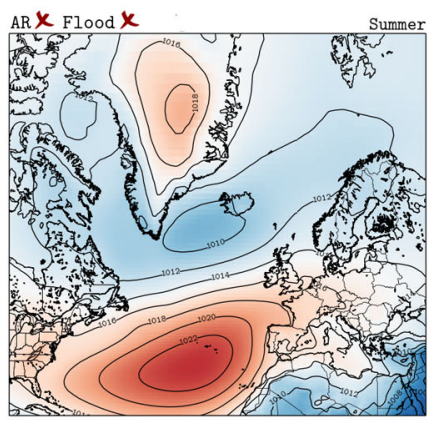

(h)

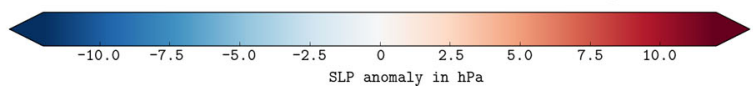

Figure 6. SLP composites for all events in the extended winter months depending on whether both an AR and an FE (a), only FEs (b), only ARs (c) or neither (d) have been detected. (e-h) The same are represented except for the extended summer months. The background field depicts anomalies, and the isolines show mean values. The composites correspond to the period 1979-2010.

coast of Galicia, there would have to be a convergence of a high-pressure center to the south of it and a low-pressure center to the north. For an AR to be detected with an FE, the previously described situation would have to occur, and the low-pressure center would have to occupy a very large space over the North Atlantic. Flooding alone, with no AR presence, would occur with any similar situation to that described above, but both pressure centers would be weakened. For the days on which neither ARs nor floods were detected, a well-developed anticyclone over the Azores was identified as being influential in blocking the passage of baroclinic systems.

In the case of the summer months, the situation is similar to that of the winter months as far as AR detection is concerned, except for FEs, which occurred concurrently with a well-developed anticyclone over the Azores islands. This peculiarity shows that floods in the summer months are not as closely related to the arrival of baroclinic structures as they are to convective precipitation, which is compatible with the idea that the Azores anticyclone forms a blocking event.

Figure 7 is analogous to Fig. 6 but shows anomalies in the IVT fields instead of the SLP. The results indicate that the detection of an AR in the winter months is contingent upon the presence of an intense IVT field over Galicia. These results are intensified when the AR is accompanied by an FE.
For cases in which no AR is detected, no intense IVT fields are observed over the studied region, especially when an FE is also not detected. With respect to the summer months, no significant qualitative differences are detected in relation to the winter months.

Figure A2 is comparable to Figs. 6 and 7, but herein the IWV field is represented. As revealed by this figure, both for the summer and winter months, more pronounced IWV anomalies were observed for Galicia when an AR was detected. It is also of note that flooding was associated with disturbances in the IWV fields. These conclusions are similar to those drawn from Fig. 6 . The results are much less pronounced, due to the fact that the IWV fields are much more stable than the IVT fields. Additionally, the presence of an AR suggests a disturbance in the IWV fields that is much more spatially localized than in the case of IVT, and therefore the imprint it leaves on the climatic composite is much lower.

\section{Conclusions}

The flooding episodes in the months between October and March in the coastal areas of Galicia (NW Spain) are associated with WTs of W, NW and C. These WTs are related to inbound baroclinic structures, Atlantic storms and ARs on 


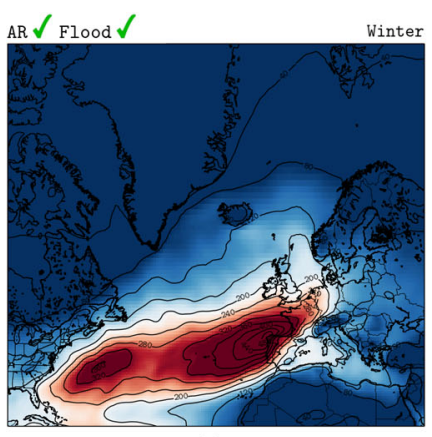

(a)

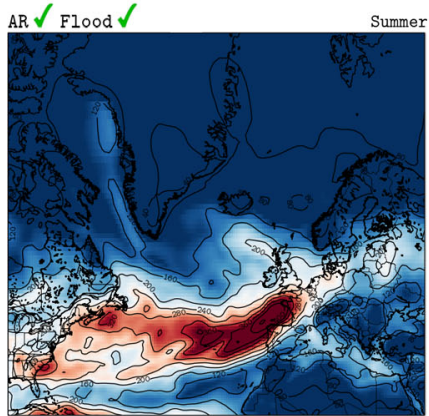

(e)

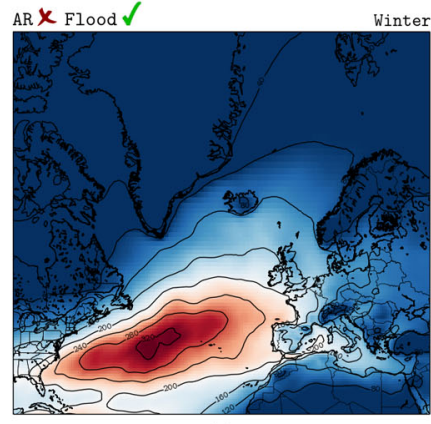

(b)

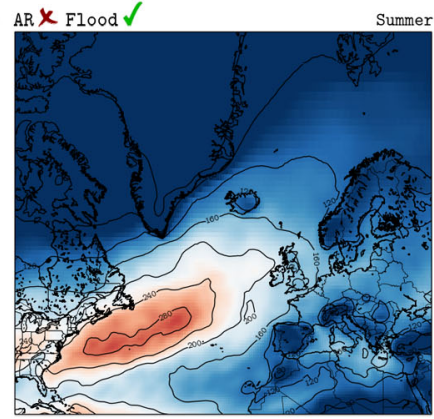

(f)

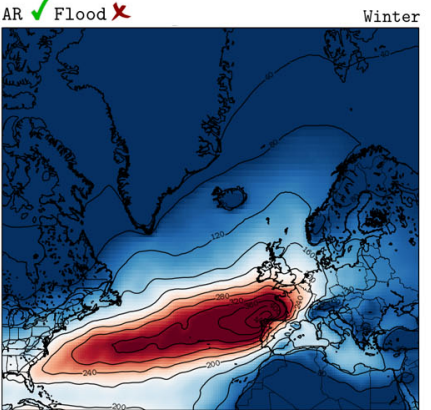

(c)

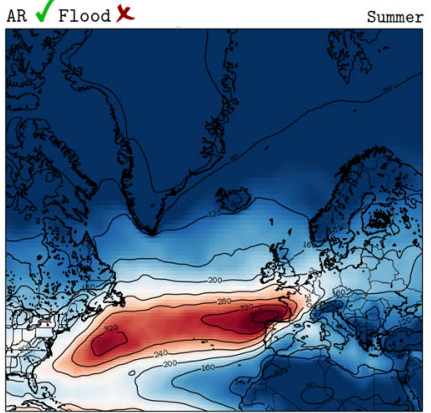

(g)

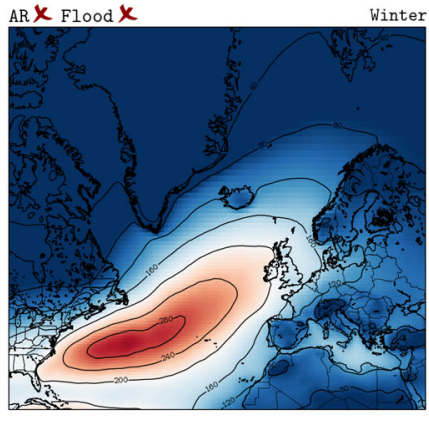

(d)

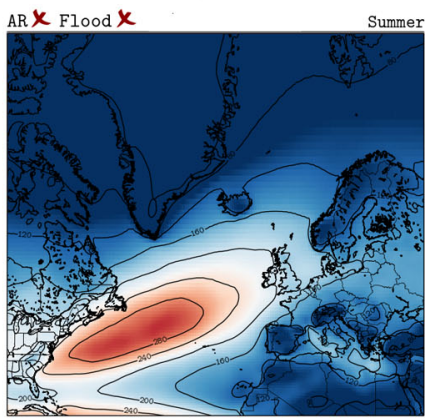

(h)

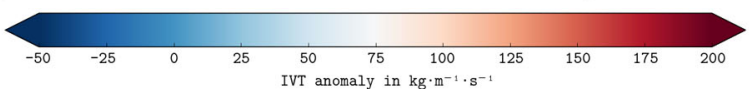

Figure 7. Same as Fig. 6 but with IVT values.

the Galicia coast. Our results support the critical role that ARs play in the intensification of flood episodes, which are present in $70 \%$ of the most important FEs in coastal areas, and provide enough moisture to increase the total accumulated rainfall.

The link between ARs and FEs is not so evident in coastal areas throughout the summer months, nor is it evident year round in the inland basin. It is likely that this is due to the more convective nature of precipitation in extreme events far from the coast and in the extended summer months. It should be noted that most of the FEs in Galicia do not coincide with an AR in both coastal and inland areas and during both summer and winter months. However, the expected precipitation of an FE is more than doubled if an AR is detected under any synoptic condition.
The ideas stated in this paper may only be useful to predict FEs along with an operative AR detection algorithm for the Iberian Atlantic Margin. With this aim, we have developed the first operative AR detection system for Europe, which can be accessed at http://meteo.usc.es/ARs (last access: June 2018). Regarding future work, flood catalogues will allow researchers to perform higher-resolution analyses, in order to improve the identification of risk areas, as well as to better determine any correlations between floods, ARs and WTs.

Data availability. No public data are derived from this research. For further information, please contact the corresponding author. 


\section{Appendix A: Supplementary material}

Table A1. Information regarding the meteorological stations.

\begin{tabular}{llcclll}
\hline Station & Province & Latitude & Longitude & Agency & Type & Region \\
\hline Coruña & Coruña & $43^{\circ} 22^{\prime} 1^{\prime \prime} \mathrm{N}$ & $8^{\circ} 25^{\prime} 9.9^{\prime \prime} \mathrm{W}$ & AEMET & Manual & COSTA \\
Lourizán & Pontevedra & $42^{\circ} 24^{\prime} 37.8^{\prime \prime} \mathrm{N}$ & $8^{\circ} 39^{\prime} 46.1^{\prime \prime} \mathrm{W}$ & MeteoGalicia & Automatic and manual & COSTA \\
Lugo & Lugo & $43^{\circ} 0^{\prime} 40.0^{\prime \prime} \mathrm{N}$ & $7^{\circ} 33^{\prime} 17.0^{\prime \prime} \mathrm{W}$ & AEMET & Manual & SIL \\
Orense & Orense & $42^{\circ} 19^{\prime} 40.0^{\prime \prime} \mathrm{N}$ & $7^{\circ} 51^{\prime} 37.0^{\prime \prime} \mathrm{W}$ & AEMET & Manual & SIL \\
Santiago & Coruña & $42^{\circ} 52^{\prime} 12.0^{\prime \prime} \mathrm{N}$ & $8^{\circ} 33^{\prime} 2.6^{\prime \prime} \mathrm{W}$ & AEMET & Manual & COSTA \\
\hline
\end{tabular}

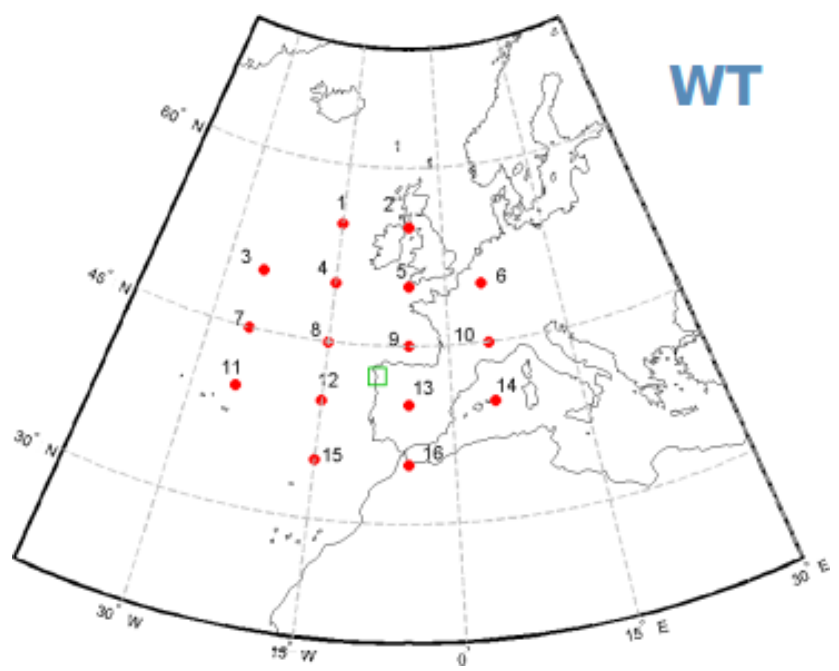

Figure A1. Pressure grid points used in the characterization of the WTs. 

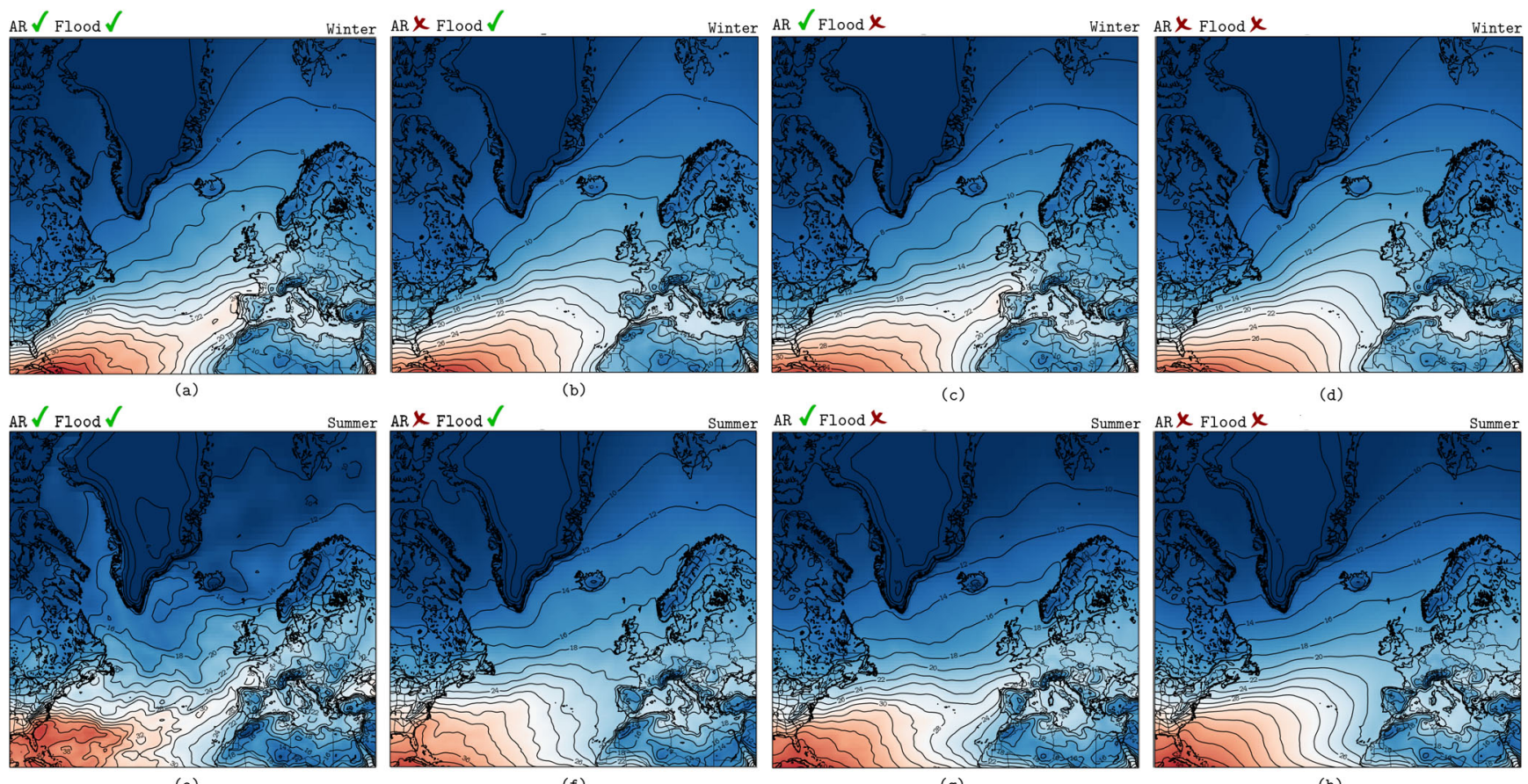

(g)

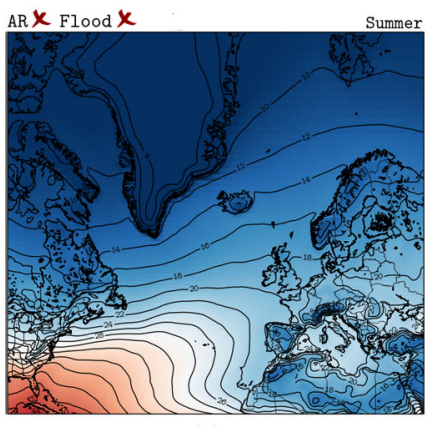

(h)

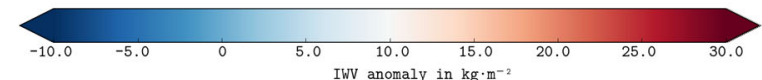

Figure A2. Same as Figs. 6 and 7 but with IWV values. 
Table A2. FEs included in the analysis, listed in descending order of precipitation amount for the COSTA region.

\begin{tabular}{|c|c|c|c|c|c|}
\hline Event & Region & $\begin{array}{l}\text { Day of } \\
\text { max. precipitation }\end{array}$ & $\begin{array}{r}\text { Amount of } \\
\text { precipitation }(\mathrm{mm})\end{array}$ & $\begin{array}{c}\text { AR } \\
\text { detection }\end{array}$ & WT \\
\hline 13-16 Oct 1987 & COSTA & 14 Oct 1987 & 286.8 & 1 & $\mathrm{~W}$ \\
\hline 19-21 1989 & COSTA & 19 Dec 1989 & 253.7 & 1 & SW \\
\hline 7-9 1999 & COSTA & 8 Mar 1999 & 253.6 & 1 & $\mathrm{C}$ \\
\hline 20 Oct $2000-10$ Jan 2001 & COSTA & 6 Dec 2000 & 202.8 & 1 & SW \\
\hline $2-25$ Oct 2006 & COSTA & 21 Oct 2006 & 189.1 & 1 & SW \\
\hline 11 Nov-31 Dec 2002 & COSTA & 12 Nov 2002 & 185.0 & 0 & $\mathrm{~W}$ \\
\hline 13 Nov-29 Dec 2009 & COSTA & 5 Dec 2009 & 182.1 & 1 & SW \\
\hline 21 Feb-1 Mar 2010 & COSTA & $21 \mathrm{Feb} 2010$ & 181.2 & 1 & $\mathrm{C}$ \\
\hline 19-23 Oct 2001 & COSTA & 21 Oct 2001 & 179.9 & 1 & SW \\
\hline 3-9 Oct 2010 & COSTA & 8 Oct 2010 & 160.0 & 0 & $\mathrm{~S}$ \\
\hline 21 Dec 1995-23 Jan 1996 & COSTA & 23 Dec 1995 & 156.9 & 1 & $\mathrm{~W}$ \\
\hline 5-5 Jan 1988 & COSTA & 5 Jan 1988 & 145.9 & 1 & $\mathrm{CW}$ \\
\hline 18 Nov-7 Dec 2006 & COSTA & 27 Nov 2006 & 139.2 & 1 & SW \\
\hline 19-24 Mar 2001 & COSTA & 20 Mar 2001 & 105.2 & 1 & $\mathrm{CW}$ \\
\hline 24 Apr-25 May 2000 & COSTA & 24 Apr 2000 & 103.9 & 1 & $\mathrm{CW}$ \\
\hline 28 Oct-2 Nov 2005 & COSTA & 29 Oct 2005 & 103.0 & 1 & SW \\
\hline 12-23 Jan 2010 & COSTA & 22 Jan 2010 & 88.2 & 0 & $\mathrm{~W}$ \\
\hline 10-13 Nov 1997 & COSTA & 10 Nov 1997 & 83.0 & 1 & $\mathrm{~W}$ \\
\hline 30 Apr-1 May 1998 & COSTA & 30 Apr 1998 & 66.0 & 0 & $\mathrm{~N}$ \\
\hline 9-11 Jun 2010 & COSTA & 10 Jun 2010 & 63.6 & 0 & $\mathrm{C}$ \\
\hline 4 Apr-8 Sep 2004 & COSTA & 4 Sep 2004 & 62.6 & 0 & ANE \\
\hline 6-6 Nov 1994 & COSTA & 6 Nov 1994 & 41.7 & 0 & $\mathrm{CW}$ \\
\hline 23-25 Jan 2009 & COSTA & 24 Jan 2009 & 40.8 & 1 & $\mathrm{~W}$ \\
\hline 15-21 Jun 1988 & COSTA & 15 Jun 1988 & 27.9 & 0 & $\mathrm{NE}$ \\
\hline
\end{tabular}

Table A3. FEs included in the analysis, listed in descending order of precipitation amount for the SIL region.

\begin{tabular}{lllccl}
\hline Event & Region & $\begin{array}{l}\text { Day of } \\
\text { max. precipitation }\end{array}$ & $\begin{array}{c}\text { Amount of } \\
\text { precipitation (mm) }\end{array}$ & $\begin{array}{c}\text { AR } \\
\text { detection }\end{array}$ & WT \\
\hline 14-16 Oct 1987 & SIL & 15 Oct 1987 & 95.4 & 1 & C \\
31 Dec 1994-1 Jan 1995 & SIL & 31 Dec 1994 & 88.7 & 1 & NW \\
12-24 Dec 1989 & SIL & 16 Dec 1989 & 69.2 & 1 & CW \\
1-17 Jan 1994 & SIL & 5 Jan 1994 & 68.1 & 1 & W \\
24 Dec 1995-2 Jan 1996 & SIL & 30 Dec 1995 & 66.6 & 0 & CW \\
1-30 Nov 1996 & SIL & 22 Nov 1996 & 60.2 & 0 & W \\
10-12 Jan 1991 & SIL & 10 Jan 1991 & 58.4 & 1 & W \\
14-16 Dec 1999 & SIL & 14 Dec 1999 & 56.8 & 1 & NW \\
6-13 Jan 1996 & SIL & 6 Jan 1996 & 50.2 & 0 & CW \\
15-21 Jun 1988 & SIL & 15 Jun 1988 & 46.4 & 0 & NE \\
30 Oct 2000-31 Mar 2001 & SIL & 21 Nov 2000 & 36.5 & 1 & W \\
5-13 Dec 2000 & SIL & 7 Dec 2000 & 29.9 & 0 & CW \\
30 Apr-4 May 1998 & SIL & 30 Apr 1998 & 26.6 & 0 & N \\
1 Nov-31 Dec 2002 & SIL & 20 Nov 2002 & 24.7 & 0 & SW \\
1-31 Dec 2003 & SIL & 9 Dec 2003 & 12.6 & 0 & C \\
27-27 Dec 2003 & SIL & 27 Dec 2003 & 12.6 & 1 & C \\
\hline
\end{tabular}


Competing interests. The authors declare that they have no conflict of interest.

Acknowledgements. The authors acknowledge fruitful discussions with Swen Brands and MeteoGalicia. Jorge Eiras-Barca is funded by the "Ministerio Español de Economía y Competitividad" and FEDER (EDRF) (CGL2013-45932-R). This work was partially supported by Xunta de Galicia under project "gts0005 ED431C 2017/64-GRC" Programa de Consolidación e Estruturación de Unidades de Investigación Competitivas (Grupos de Referencia Competitiva).

Edited by: Maria-Carmen Llasat

Reviewed by: two anonymous referees

\section{References}

Brands, S., Gutiérrez, J., and San-Martín, D.: Twentieth-century atmospheric river activity along the west coasts of Europe and North America: algorithm formulation, reanalysis uncertainty and links to atmospheric circulation patterns, Clim. Dynam., 48, 2771, https://doi.org/10.1007/s00382-016-3095-6, 2016.

Bueh, C. and Nakamura, H.: Scandinavian pattern and its climatic impact, Q. J. Roy. Meteorol. Soc., 133, 2117-2131, 2007.

Cabalar-Fuentes, M.: Los tetemporales de lluvia y viento en Galicia. Propuestas de clasificación y análisis de tendencias (1961-2001), Investigaciones Geográficas, 36, 103-118, 2005.

Cortesi, N., Gonzalez-Hidalgo, J. C., Trigo, R. M., and Ramos, A. M.: Weather types and spatial variability of precipitation in the Iberian Peninsula, Int. J. Climatol., 34, 2661-2677, 2014.

Dee, D. P., Uppala, S. M., Simmons, A. J., Berrisford, P., Poli, P., Kobayashi, S., Andrae, U., Balmaseda, M. A., Balsamo, G., Bauer, P., Bechtold, P., Beljaars, A. C. M., van de Berg, L., Bidlot, J., Bormann, N., Delsol, C., Dragani, R., Fuentes, M., Geer, A. J., Haimberger, L., Healy, S. B., Hersbach, H., Hólm, E. V., Isaksen, L., Kållberg, P., Köhler, M., Matricardi, M., McNally, A. P., Monge-Sanz, B. M., Morcrette, J.-J., Park, B.-K., Peubey, C., de Rosnay, P., Tavolato, C., Thépaut, J.-N., and Vitart, F.: The ERA-Interim reanalysis: configuration and performance of the data assimilation system, Q. J. Roy. Meteorol. Soc., 137, 553597, https://doi.org/10.1002/qj.828, 2011.

Dettinger, M.: Climate Change, Atmospheric Rivers, and Floods in California - A Multimodel Analysis of Storm Frequency and Magnitude Changes, J. Am. Water Resour. Assoc., 47, 514-523, https://doi.org/10.1111/j.1752-1688.2011.00546.x, 2011.

Eiras-Barca, J., Brands, S., and Miguez-Macho, G.: Seasonal variations in north atlantic atmospheric river activity and associations with anomalous precipitation over the iberian atlantic margin, J. Geophys. Res.-Atmos., 121, 931-948, https://doi.org/10.1002/2015JD023379, 2016.

Garaboa-Paz, D., Eiras-Barca, J., Huhn, F., and Pérez-Muñuzuri, V.: Lagrangian coherent structures along atmospheric rivers, Chaos, 25, 063105, https://doi.org/10.1063/1.4919768, 2015.

Gilabert, J. and Llasat, M. C.: Circulation weather types associated with extreme flood events in Northwestern Mediterranean, Int. J. Climatol., 38, 1864-1876, 2018.
Gimeno, L., Drumond, A., Nieto, R., Trigo, R. M., and Stohl, A.: On the origin of continental precipitation, Geophys. Res. Lett., 37, L13804, https://doi.org/10.1029/2010GL043712, 2010.

Gimeno, L., Nieto, R., Vázquez, M., and Lavers, D. A.: Atmospheric rivers: a mini-review, Front. Earth Sci., 2, 2, https://doi.org/10.3389/feart.2014.00002, 2014.

Gimeno, L., Dominguez, F., Nieto, R., Trigo, R., Drumond, A., Reason, C. J., Taschetto, A. S., Ramos, A. M., Kumar, R., and Marengo, J.: Major mechanisms of atmospheric moisture transport and their role in extreme precipitation events, Annu. Rev. Environ. Resour., 41, 117-141, 2016.

Guan, B. and Waliser, D. E.: Detection of atmospheric rivers: Evaluation and application of an algorithm for global studies, J. Geophys. Res.-Atmos., 120, 12514-12535, 2015.

Interior: Catálogo Nacional de Inundaciones Históricas, Dirección General de Protección Civil y Emergencias, Ministerio del Interior español, http://www.proteccioncivil.es/catalogo/naturales/ cnih/cnih2014/Presentacion.html (last access: June 2018), 2014.

Jenkinson, A. and Collison, F.: An initial climatology of gales over the North Sea, Synoptic Climatology Branch Memorandum, No. 62, Meteorological Office, Bracknell, available at the National Meteorological Library, Meteorological Office, Bracknell, UK, 1977.

Jones, P., Hulme, M., and Briffa, K.: A comparison of Lamb circulation types with an objective classification scheme, Int. J. Climatol., 13, 655-663, 1993.

Lavers, D. A. and Villarini, G.: The nexus between atmospheric rivers and extreme precipitation across Europe, Geophys. Res. Lett., 40, 3259-3264, https://doi.org/10.1002/grl.50636, 2013.

Lavers, D. A., Allan, R. P., Wood, E. F., Villarini, G., Brayshaw, D. J., and Wade, A. J.: Winter floods in Britain are connected to atmospheric rivers, Geophys. Res. Lett., 38, L23803, https://doi.org/10.1029/2011GL049783, 2011.

Lavers, D. A., Villarini, G., Allan, R. P., Wood, E. F., and Wade, A. J.: The detection of atmospheric rivers in atmospheric reanalyses and their links to British winter floods and the large-scale climatic circulation, J. Geophys. Res.-Atmos., 117, D20106, https://doi.org/10.1029/2012JD018027, 2012.

Lorenzo, M. N. and Taboada, J.: Influences of atmospheric variability on freshwater input in Galician Rias in winter, J. Atmos. Ocean Sci., 10, 377-387, 2005.

Lorenzo, M. N., Taboada, J. J., Sarmiento, M., Alvarez, I., GomezGesteira, M., DeCastro, M., Lorenzo, N., Taboada, J., Sarmiento, M., Alvarez, I., and Gomez-Gesteira, M.: Influence of teleconnection patterns on precipitation variability and on river flow regimes in the Miño River basin (NW Iberian Peninsula), Clim. Res., 32, 63-73, 2006.

Lorenzo, M. N., Taboada, J., and Gimeno, L.: Links between circulation weather types and teleconnection patterns and their influence on precipitation patterns in Galicia (NW Spain), Int. J. Climatol., 28, 1493-1505, 2008.

Lorenzo, M. N., Ramos, A. M., Taboada, J. J., and Gimeno, L.: Changes in present and future circulation types frequency in northwest Iberian Peninsula, PloS One, 6, e16201, https://doi.org/10.1371/journal.pone.0016201, 2011.

Martínez, E. G. and Ezpeleta, A. M.: Riesgos climáticos en Galicia: una aproximación a través de la prensa (1983-1997), Ería, Revista Cuatrimestral de Geografía, Universidad de Oviedo, Oviedo, Spain, 259-269, 2000. 
Matrosov, S. Y.: Characteristics of landfalling atmospheric rivers inferred from satellite observations over the eastern North Pacific Ocean, Mon. Weather Rev., 141, 3757-3768, 2013.

Neiman, P. J., Hughes, M., Moore, B. J., Ralph, F. M., and Sukovich, E. M.: Sierra barrier jets, atmospheric rivers, and precipitation characteristics in northern California: A composite perspective based on a network of wind profilers, Mon. Weather Rev., 141, 4211-4233, 2013.

Newell, R. E., Newell, N. E., Zhu, Y., and Scott, C.: Tropospheric rivers? - A pilot study, Geophys. Res. Lett., 19, 2401-2404, https://doi.org/10.1029/92GL02916, 1992.

Nieto, R., Taboada, J., Crespo, A., Ramos, A., Iglesias, I., GómezGesteira, J., Santo, F., Barriopedro, D., and Trigo, I.: The state of climate in NW Iberia, Clim. Res., 48, 109-144, 2011.

Ralph, F. M. and Dettinger, M. D.: Storms, floods, and the science of atmospheric rivers, Eos Trans. Am. Geophys. Un., 92, 265-266, https://doi.org/10.1029/2011EO320001, 2011.

Ralph, F. M., Neiman, P. J., Wick, G. A., Gutman, S. I., Dettinger, M. D., Cayan, D. R., and White, A. B.: Flooding on California's Russian River: Role of atmospheric rivers, Geophys. Res. Lett., 33, L13801, https://doi.org/10.1029/2006GL026689, 2006.

Ramos, A. M.: Improving circulation weather type classification using a 3D framework: relationship with climate variability and projections for future climates, $\mathrm{PhD}$ thesis, University Vigo, Vigo, 2012.
Ramos, A. M., Trigo, R. M., Liberato, M. L. R., and Tomé, R.: Daily precipitation extreme events in the Iberian Peninsula and its association with Atmospheric Rivers, J. Hydrometeorol., 16, 579-597, https://doi.org/10.1175/JHM-D-14-0103.1, 2015.

Rutz, J. J., Steenburgh, W. J., and Ralph, F. M.: Climatological characteristics of atmospheric rivers and their inland penetration over the western United States, Mon. Weather Rev., 142, 905-921, 2014.

Trigo, R. M. and DaCamara, C. C.: Circulation weather types and their influence on the precipitation regime in Portugal, Int. J. Climatol., 20, 1559-1581, https://doi.org/10.1002/10970088(20001115)20:13<1559::AID-JOC555>3.0.CO;2-5, 2000.

Trigo, R. M., Valente, M. A., Trigo, I. F., Miranda, P., Ramos, A. M., Paredes, D., and García-Herrera, R.: The impact of North Atlantic wind and cyclone trends on European precipitation and significant wave height in the Atlantic, A. New York Acad. Sci., 1146, 212-234, 2008.

Waliser, D. and Guan, B.: Extreme winds and precipitation during landfall of atmospheric rivers, Nat. Geosci., 10, 179-183, 2017.

Zhu, Y. and Newell, R. E.: A Proposed Algorithm for Moisture Fluxes from Atmospheric Rivers, Mon. Weather Rev., 126, 725-735, https://doi.org/10.1175/15200493(1998)126<0725:APAFMF>2.0.CO;2, 1998. 